\title{
Settlement, colonization, and succession patterns of gold coral Kulamanamana haumeaae in Hawaiian deep coral assemblages
}

\author{
Frank A. Parrish* \\ Pacific Islands Fisheries Science Center, NOAA Inouye Regional Center, 1845 Wasp Blvd., Building 176, Honolulu, \\ Hawaii 96818, USA
}

\begin{abstract}
The Hawaiian gold coral is a parasitic zoantharian that colonizes other deep corals and secretes a protein skeleton that over millennia can grow and more than double the original mean size of the host colony. Surveys at 6 known coral beds in the Hawaiian Archipelago found mature gold coral to be a common taxon and dominant at the geologically older sites. Fewer than $5 \%$ of the gold coral colonies seen were in the process of subsuming their host, described here as the 'midas' phase. Bamboo coral (Acanella, Keratoisis) comprised $85 \%$ of the midas colonies, with two-thirds found at the youngest site, where the mean height of bamboo coral was significantly greater than at other sites. Marked midas colonies revisited after $5 \mathrm{yr}$ showed the gold coral tissue spreading across the host at an estimated rate of $2.2 \pm 0.69 \mathrm{~cm} \mathrm{yr}^{-1}$ (mean $\pm \mathrm{SD}$ ). Cross sections of mature gold coral colonies show the host averages just $9.8 \mathrm{~cm}$ of the stem's core, indicating that much of the host skeleton is lost when subsumed by gold coral tissue. The absence of midas colonies in a bamboo coral assemblage found growing on a $76 \mathrm{yr}$ old wreck close $(\sim 1 \mathrm{~km})$ to a mature gold coral patch suggests that gold coral recruitment is infrequent. This time lag between the growth of the host and the arrival of the gold coral successor is essential because otherwise the speed of the midas phase would subsume the host population faster than it could replenish.
\end{abstract}

KEY WORDS: Parasitism · Pioneer settlement $\cdot$ Climax community $\cdot$ Recruitment $\cdot$ Host-limited

\section{INTRODUCTION}

Hawaiian gold coral Kulamanamana haumeaae (Sinniger et al. 2013), of the family Parazoanthidae, is an important taxon of Hawaiian deep-sea corals because of the role its parasitic life history and longevity play in the structure of the deep-sea community. It was referred to as Gerardia sp. (Lacaze-Duthiers, 1864) and historically was recognized as a synonym of Savalia (Nardo, 1844). As a zoanthid, its planula settles on and colonizes other coral fans, spreading over their surface to subsume the host completely. For the purposes of this paper, the term sea fans will be used to describe the mix of potential deep-sea coral hosts exclusive of scleractinian crustose corals (e.g. Corallidae, Dendrophyliidae), which have not

\footnotetext{
${ }^{*}$ Corresponding author: frank.parrish@noaa.gov
}

been documented as a host. Unlike other zoanthids (Sinniger et al. 2013), gold coral secretes a scleroproteic skeleton that covers the colony base, the stem, and forms branches that extend well beyond the initial dimensions of the host. Gold coral tissue is highly reflective when illuminated and like some other deep corals (Muzik 1978) is bioluminescent when physically brushed. With the tissue removed, the skeleton appears smooth, shiny, and gold in color, hence the name. Large colonies of gold coral were harvested (1974 to 2001) (Parrish \& Baco 2007) as raw material for the jewelry trade, and anecdotal observations identified bamboo corals as a common host (Grigg 1993, 2001). The overall height of a colony was used as a proxy for age and served as an important fishery metric that was the subject of growth studies using

Outside the USA @ US Government 2015. Open Access under Creative Commons by Attribution Licence. Use, distribution and reproduction are unrestricted. Authors and original publication must be credited.

Publisher: Inter-Research · www.int-res.com 
stem ring counts (Grigg 2002) and radiometric dating (Druffel et al. 1995). Current estimates put the linear (or axial) growth of gold coral as slow as $2.2 \mathrm{~mm} \mathrm{yr}^{-1}$ (Roark et al. 2006, 2009, Parrish \& Roark 2009), with the largest colonies estimated to be as much as $2700 \mathrm{yr}$ in age. However, these growth estimates do not account for the parasitic aspect of gold coral's life history. The early-stage colonization and overgrowth by gold coral is of particular interest because its hosts, the branched bamboo corals of the genera Acanella and Keratoisis, have much shorter life spans. The mean axial growth of bamboo coral has been estimated at 0.14 to $1.38 \mathrm{~cm} \mathrm{yr}^{-1}$, which is equivalent to a life span between 70 and 126 yr (Roark et al. 2005, Tracey et al. 2007, Andrews et al. 2009). The dependence of a slow-growing, long-lived parasitic coral on a faster-growing, shorter-lived host suggests that once a gold planula settles, it spreads across the host at a relatively quick pace (Parrish \& Roark 2009). It is not known if an open portion of the host skeleton (e.g. tissue loss due to urchin predation; Griffith 1994, Mah et al. 2010) is needed for settlement or if a drifting gold coral planula can attach to a healthy host coral and outcompete the host tissue. Also, the dependence of gold coral on a host further complicates recruitment, which by itself is an important limitation of deep coral populations (Grigg 1988). This study addresses some of the information gaps by looking for differences in patterns of known deep coral community assemblages across the Hawaiian Archipelago's span of geologic history. Host colonies being colonized by gold coral were marked and remeasured; some other toppled gold coral colonies were collected, cross-sectioned, and examined for the presence of the carbonate host within their cores. Finally, a recent coral community growing on a vessel scuttled 76 yr ago was examined for evidence of settlement by bamboo or gold corals.

\section{METHODS}

\section{Coral community surveys}

The 'Pisces V' submersible conducted surveys of known deep coral beds at depths between 350 and $500 \mathrm{~m}$ across the Hawaiian Archipelago in 2007. Observers on the port and starboard sides of the vehicle looked through viewports that faced forward and down. The submersible's lights illuminated a $12 \mathrm{~m}$ swath, with video recording the $6 \mathrm{~m}$ center portion. Observers identified corals in the distance, and the submersible would alter course to record them on video. Height was estimated to the nearest $5 \mathrm{~cm}$ for all corals larger than $10 \mathrm{~cm}$ (the size at which they are conspicuous) by using a laser scale projected on the bottom close to the colony and recorded by video. The track of the submersible was monitored from the ship using a slant-range tracking system (TrackLink II software). Counts of corals on the survey were binned into 5 min intervals or survey segments that covered an average $55 \mathrm{~m}$ (SD 9.3) of linear distance or $330 \mathrm{~m}^{2}$ of area. Timing was stopped when the submersible was stationary on the bottom to make observations, mark colonies, collect samples, pick up temperature data loggers, or backtrack over previously surveyed ground. Survey sites included Brooks Bank, the east extension of the French Frigate Shoals (FFS) platform, the Westpac Bed located on Middle bank, the Makapuu Bed at Oahu, the Keahole Bed at the Big Island of Hawaii, and Cross Seamount (Fig. 1). Bottom topography and substrate varied across the sites and included ledges, pinnacles, and tracts of carbonate bottom. Geologic ages of the survey sites ranged from the youngest (Keahole) at 0.25 million years ago (Mya), to the older 13 Mya (Brooks Bank), to the oldest estimated at 100+ Mya (Cross Seamount) (Garcia et al. 2015) (Table 1). The

Table 1. Sites surveyed by the 'Pisces V' submersible (see Fig. 1), including dive number, geologic age (million years ago, Mya), depth, distance traveled, topography, substrate type, and mean annual temperature. At the bottom is the scuttled hull of the 'S-19' World War I submarine, and its age is listed in years. FFS: French Frigate Shoals

\begin{tabular}{|c|c|c|c|c|c|c|c|}
\hline Site & Dive no. & $\begin{array}{l}\text { Geologic age } \\
\text { (Mya) }\end{array}$ & $\begin{array}{l}\text { Depth } \\
\text { (m) }\end{array}$ & $\begin{array}{l}\text { Distance } \\
\text { (m) }\end{array}$ & Topography & Substrate & $\begin{array}{c}\text { Mean temperature } \\
\left({ }^{\circ} \mathrm{C}\right)(\mathrm{SD})\end{array}$ \\
\hline Cross & PV-704 & $100+$ & $404-421$ & 450 & Peak & Carbonate & $8.74(0.5)$ \\
\hline Brooks & PV-697 & 13 & $449-459$ & 800 & Ledge & Carbonate & NA \\
\hline FFS & PV-692 & 12 & $352-360$ & 800 & Peak & Basalt & $10.9(0.66)$ \\
\hline Westpac & PV-702 & 8 & $368-419$ & 1733 & Flat & Carbonate & NA \\
\hline Makapuu & PV-687 & 4 & $396-429$ & 772 & Flat & Carbonate & $8.23(0.43)$ \\
\hline Keahole & PV-707 & 0.25 & $382-398$ & 750 & Ledge & Carbonate & $8.5(0.79)$ \\
\hline 'S-19' & PV-827 & $75 \mathrm{yr}$ & 414 & 120 & Hull & Steel & $10.1(1.1)^{\mathrm{a}}$ \\
\hline
\end{tabular}


Fig. 1. Deep coral communities surveyed in the Hawaiian Archipelago and location of the 'S-19' World War I submarine wreck. FFS: French Frigate Shoals

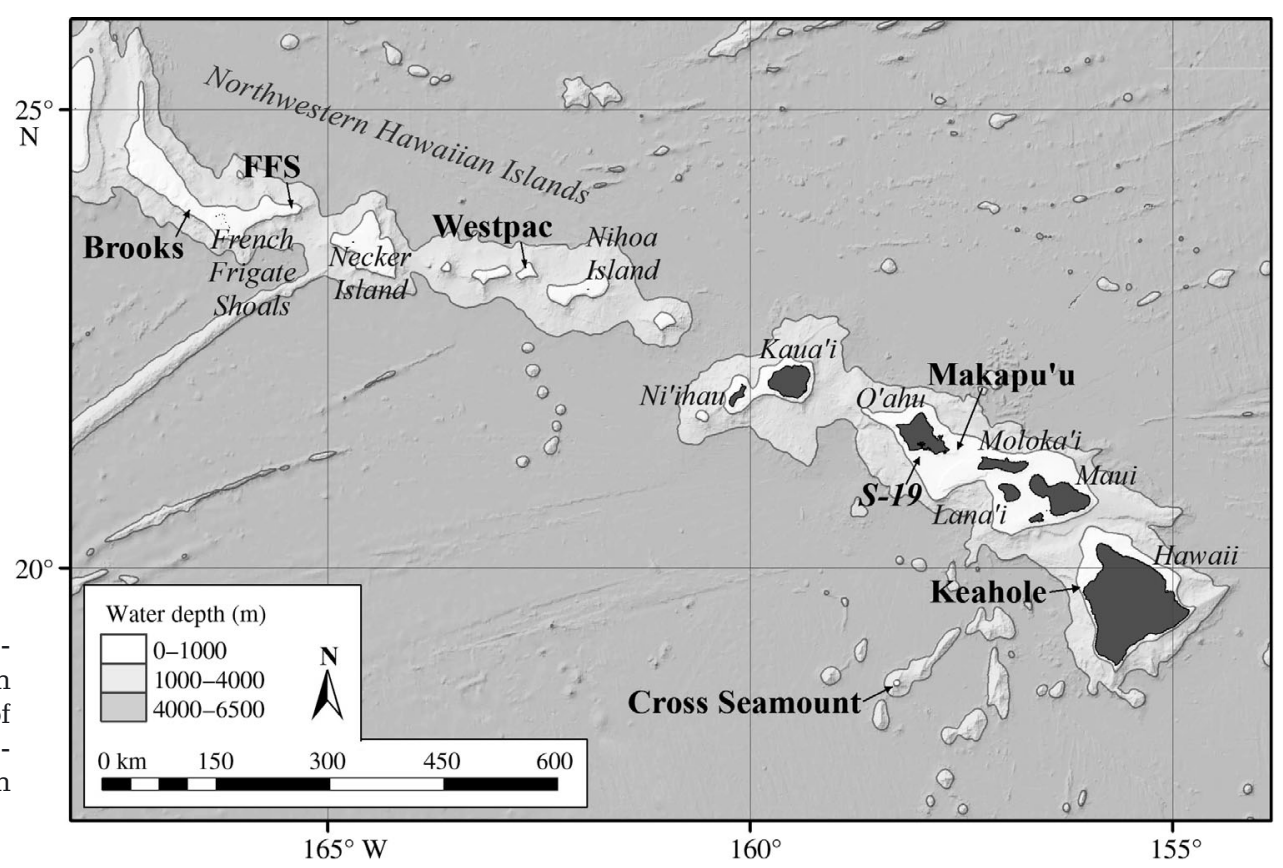

oldest and youngest sites are located together at the southeastern end of the archipelago because Cross Seamount is a Cretaceous Pacific plate feature close to the volcanic hot spot that most recently formed the emergent peak that is the Big Island of Hawaii (including the Keahole site) as well as the older peaks that form the ridge of the Hawaiian Archipelago (Tilling et al. 2010).

The visual surveys of the deep coral community were divided into 3 groups including gold coral, bamboo coral, and sea fans. The bamboo coral group included unidentified species of the genera Acanella and Keratoisis that were of branched morphology and thought to be a common host for gold coral. The sea fans group captured all of the remaining coral colonies that potentially could serve as a host for gold coral (Parrish \& Baco 2007). Colonies for each group were counted, height-estimated, photographed, and videotaped.

\section{Midas colonies and the spread of gold coral tissue}

During the 2007 surveys, any host corals found partially covered with a patch of gold coral tissue were documented. These colonies were predicted to be in the early stages of being covered and turned into full gold coral colonies (Sinniger et al. 2013), and in this transitional state, they were referred to as midas colonies. Their number, size, and host type were noted for comparison between survey sites. Four midas col- onies were marked at the Keahole site using numbered concrete flowerpots. The hosts appeared healthy, with no bare spots of open skeleton, so that any observed expansion of the gold coral tissue would be an act of displacing the healthy host tissue. Each colony was videotaped and measured with a laser scale to document the expanding patch of gold coral tissue. For each tissue patch, the number of edges that could expand along the host branch and the amount of the host left to be covered were recorded. In 2012, the colonies were revisited, and the same data were collected and compared with 2007 measurements for any change.

\section{Toppled gold coral skeletons}

A live gold coral colony marked standing in 2000 as part of a prior growth study (Parrish \& Roark 2009) was revisited in 2007 and found toppled but fully alive. Left in place, it was revisited 5 yr later in 2012 to document any changes in its condition. In addition, general observations were made on other fallen colonies found on the seafloor, with attention directed to any new growth that may have formed since the colony fell. New growth could be distinguished as a vertical extension of the protein skeleton, perpendicular to the seafloor. Nine other toppled gold corals (dead and live) were collected at Keahole, Cross Seamount, and FFS to look for evidence of the carbonate host they originally colonized. The colonies 
were photographed and sectioned to document the extent to which the host occurred within the axis of the gold coral core. Variables that were recorded include overall height of the gold coral colony, height and diameter of a carbonate host found inside, and size of the holdfast for both the gold coral and host corals.

\section{Recruitment}

A recent habitat of known age was surveyed for any recruitment by host corals and evidence of early succession by gold coral. This was accomplished by
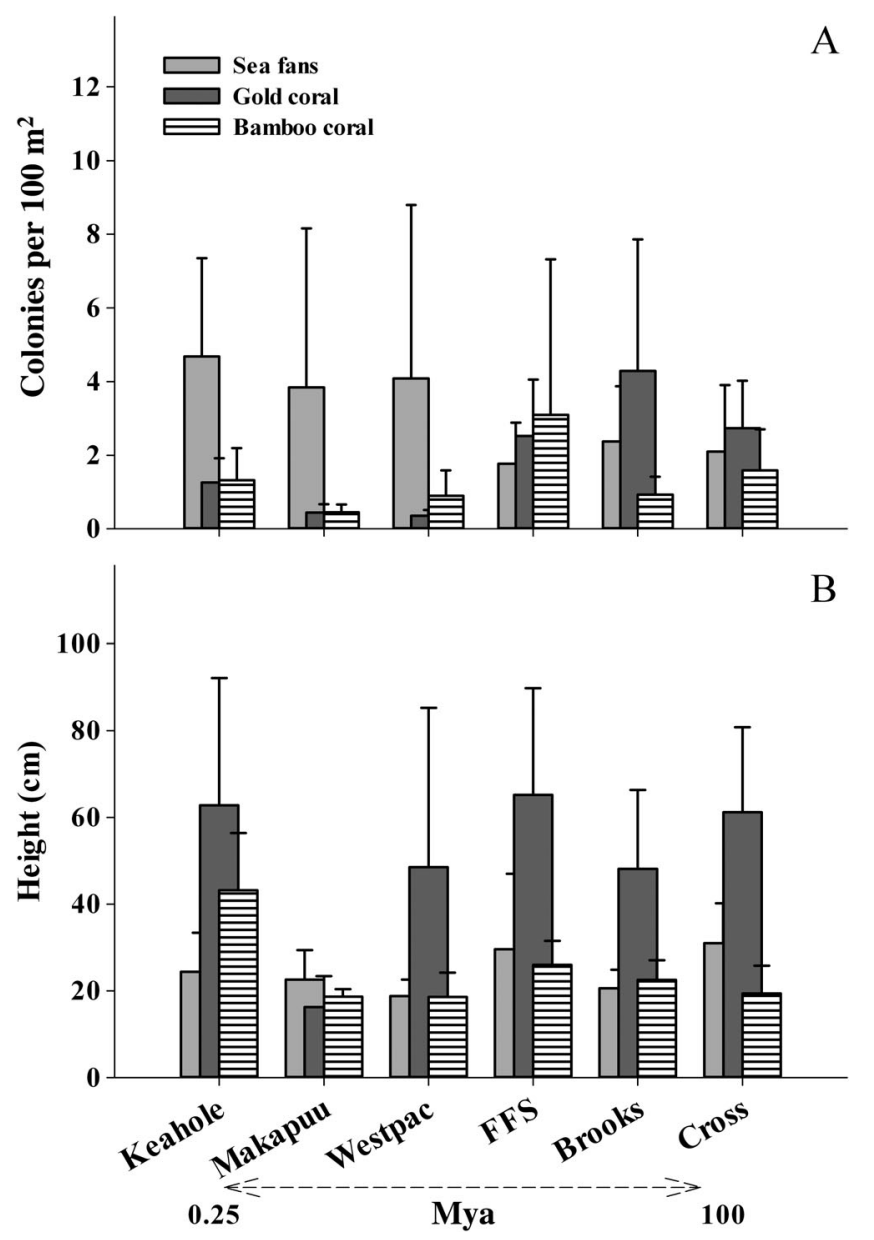

Fig. 2. (A) Mean density and SD of coral groups across the 6 survey sites, showing gold coral more abundant at older sites and the sea fan group more abundant at younger sites. (B) Mean height and SD of coral groups, showing gold coral 2 to 3 times the height of its bamboo coral host at all sites except Makapuu (location of coral harvesting) and Keahole (the youngest site). The survey sites are ordered in relation to their geologic age. FFS: French Frigate Shoals; Brooks: Brooks Bank; Cross: Cross Seamount; Mya: million years ago conducting surveys on the hull of the 'S-19,' a sunken World War I submarine (Fig. 1, Table 1). The $66 \mathrm{~m}$ long vessel was scuttled (1938) at a depth of $414 \mathrm{~m}$ in the middle of a sand field $1.3 \mathrm{~km}$ from the closest hard-bottom feature, a pinnacle $(378 \mathrm{~m})$ supporting a mature deep coral community. Multi-beam mapping data and sonar were used to verify the extent of the sand field. Both the 'S-19' and the nearby hardbottom pinnacle were surveyed, and the numbers and heights of midas colonies, mature gold coral colonies, and bamboo coral colonies were documented and compared.

\section{Analysis}

The non-normal distribution of the data required the use of non-parametric analysis. Sequential KruskalWallis (KW) analysis of variance (ANOVA) was used to compare medians. When needed, the ANOVAs were followed by stepwise multiple comparison procedures (Siegel \& Castellan 1988) to determine which groups were different. The size of the coral beds varied, resulting in an uneven distribution of the number of survey segments among sites. Where data from the sites could be combined for comparison, the sample sizes afforded a power of at least 0.80 at a large effect size, with $\alpha=0.01$ (Cohen 1988). Finally, a MannWhitney $U$-test was used to compare the height of midas colonies with those of available hosts, and Spearman rank-order correlation $\left(\mathrm{r}_{\mathrm{S}}\right)$ was used to evaluate associations in host type, rate of tissue spread, and the presence of the host at the core of the protein skeleton.

\section{RESULTS}

\section{Community patterns}

The abundance of the sea fans group varied across survey sites, while their mean size remained relatively constant. The greatest numbers were found at the 3 geologically youngest sites (KW $\chi^{2}=24.78, \mathrm{p}<$ $0.001)$; this was also where the gold coral was seen in lowest abundance (Fig. 2A). The mean height of the sea fans group was comparable to the height of the bamboo coral group at all of the sites except Keahole, where the bamboo coral colonies were taller (Fig. 2B). The corals that comprised the sea fans group all occurred as a low percent of the total seen, and there was no obvious pattern across the surveyed sites (Table 2). 
Table 2. Taxa that comprised the sea fans group, with presence by survey site and taxon-specific percent composition of the total overall sites

\begin{tabular}{|c|c|c|c|c|c|c|c|}
\hline Taxon & $\begin{array}{c}\text { Cross } \\
\text { Seamount }\end{array}$ & $\begin{array}{c}\text { Brooks } \\
\text { Bank }\end{array}$ & $\begin{array}{c}\text { French Frigate } \\
\text { Shoals }\end{array}$ & Westpac & Makapuu & Keahole & $\begin{array}{c}\text { Composition } \\
(\%)\end{array}$ \\
\hline \multicolumn{8}{|l|}{ HEXACORALLIA } \\
\hline \multicolumn{8}{|l|}{ Antipatharia } \\
\hline Antipatharian & $\mathrm{X}$ & $\mathrm{X}$ & $\mathrm{X}$ & $\mathrm{X}$ & $\mathrm{X}$ & $\mathrm{X}$ & 0.09 \\
\hline Cirrhipathes sp. & & & & $\mathrm{X}$ & & & 0.033 \\
\hline Aphanipathes sp. & & $\mathrm{X}$ & $\mathrm{X}$ & $\mathrm{X}$ & & & 0.07 \\
\hline Leiopathes sp. & & $\mathrm{X}$ & $\mathrm{X}$ & $\mathrm{X}$ & $\mathrm{X}$ & & 0.012 \\
\hline Bathypathes sp. & & $\mathrm{X}$ & $\mathrm{X}$ & $\mathrm{X}$ & $\mathrm{X}$ & $\mathrm{X}$ & 0.053 \\
\hline \multicolumn{8}{|l|}{ Zoanthidea } \\
\hline Parazoanthid & $\mathrm{X}$ & $\mathrm{X}$ & $\mathrm{X}$ & $\mathrm{X}$ & & $\mathrm{X}$ & 0.052 \\
\hline \multicolumn{8}{|l|}{ OCTOCORALLIA } \\
\hline Gorgonian & $\mathrm{X}$ & $\mathrm{X}$ & $\mathrm{X}$ & $\mathrm{X}$ & & $\mathrm{X}$ & 0.012 \\
\hline Acanthogorgia sp. & & & & $\mathrm{X}$ & & & 0.0008 \\
\hline Eunicella sp. & & & & & $\mathrm{X}$ & & 0.021 \\
\hline Lepidisis sp. & & & $\mathrm{X}$ & & $\mathrm{X}$ & & 0.021 \\
\hline Paragorgia spp. & $\mathrm{X}$ & $\mathrm{X}$ & & & & & 0.04 \\
\hline Plexaurid & $\mathrm{X}$ & $\mathrm{X}$ & & & & $\mathrm{X}$ & 0.07 \\
\hline Bebryce sp. & & $\mathrm{X}$ & & & $\mathrm{X}$ & & 0.004 \\
\hline Paramuriceid & & & & $\mathrm{X}$ & $\mathrm{X}$ & & 0.06 \\
\hline Primnoid & $\mathrm{X}$ & $\mathrm{X}$ & $\mathrm{X}$ & $\mathrm{X}$ & $\mathrm{X}$ & $\mathrm{X}$ & 0.063 \\
\hline Callogorgia sp. & $\mathrm{X}$ & & & & $\mathrm{X}$ & & 0.0169 \\
\hline Calyptrophora sp. & $\mathrm{X}$ & $\mathrm{X}$ & & $\mathrm{X}$ & & & 0.0064 \\
\hline Narella spp. & & $\mathrm{X}$ & $\mathrm{X}$ & $\mathrm{X}$ & & $\mathrm{X}$ & 0.01 \\
\hline Paracalyptrophora sp. & $\mathrm{X}$ & $\mathrm{X}$ & & $\mathrm{X}$ & & $\mathrm{X}$ & 0.045 \\
\hline Thouarella sp. & & $\mathrm{X}$ & & & $\mathrm{X}$ & & 0.04 \\
\hline \multicolumn{8}{|l|}{ Pennatulacea } \\
\hline Calibelemnon sp. & $\mathrm{X}$ & & & & & & 0.07 \\
\hline Pennatula spp. & $\mathrm{X}$ & & & & & $\mathrm{X}$ & 0.01 \\
\hline
\end{tabular}

The abundance of the bamboo coral group did not significantly differ among sites $\left(\mathrm{KW} \chi^{2}=8.59, \mathrm{df}=5\right.$, $\mathrm{p}=0.126$ ) and was roughly equal to the number of gold coral colonies except at the geologically older sites of Cross Seamount and Brooks Bank, where gold coral was more abundant (Fig. 2A). The mean $( \pm$ SD) height of gold coral colonies $(54 \pm 37 \mathrm{~cm})$ was twice that of bamboo coral $(25.9 \pm 13.7 \mathrm{~cm})$ at all of the sites except Makapuu and Keahole (Fig. 2B). At the Makapuu site, the gold corals were unusually small, but this was expected because the precious coral fishery was almost entirely focused there. More interesting is the Keahole site, where the bamboo corals were significantly taller $(43.3 \pm 13.2 \mathrm{~cm})\left(\mathrm{KW} \chi^{2}=25.9, \mathrm{p}<0.001\right.$; Fig. 2B) even though they looked like the same species based on the consistent morphology and color.

\section{Midas colonies}

The surveys encountered 20 midas colonies, half of them found at the Keahole site (Fig. 3), and this pat-

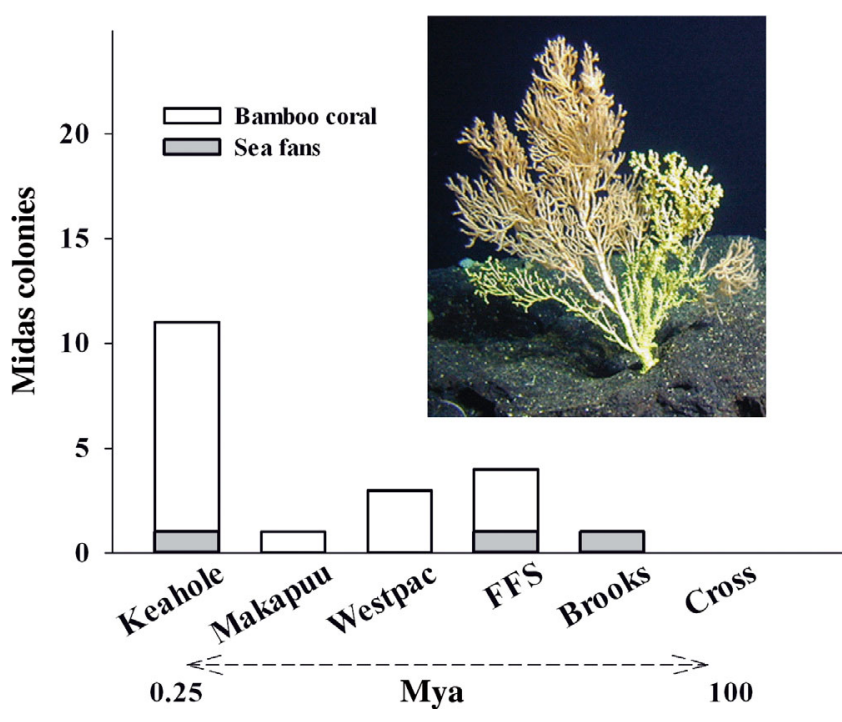

Fig. 3. Number of 'midas' colonies (i.e. gold-coral parasitism in progress) by survey site, with fill pattern indicating that the preferred host type is bamboo coral. Inset shows a midas colony using the lower portion of a bamboo coral host. Survey sites are ordered in relation to their geologic age. FFS:

French Frigate Shoals; Mya: million years ago 
tern persists even if numbers are normalized by the area surveyed $\left(r_{S}=0.986, p<0.001\right)$. The fluorescing of gold coral tissue made it possible to detect a patch as small as $\sim 2 \mathrm{~cm}^{2}$ (equal to $\sim 9$ polyps). Nearly all hosts of the midas colonies $(85 \%)$ were from the bamboo coral group, and their mean size $(37.9 \mathrm{~cm}$, SD 25.6) did not significantly differ from the mean height of other sea fans used as hosts (Mann-Whitney $U$-test, $\mathrm{Z}=23, \mathrm{p}=0.84$ ) (Fig. 3). Most of the midas colonies had their gold coral patch encrusting the hosts somewhere from their base to mid-height. Two of the colonies were found encrusted centrally without the base being covered. The gold coral tissue was mostly opaque, suggesting the presence of the protein skeletal material forming between the gold coral tissues and the host skeleton (Sinniger et al. 2013). The translucent areas were found along the advancing edges, where it was possible to see the black nodes of the host skeleton showing through gold tissue.

The expansion of the gold coral tissue patches on the 4 marked midas colonies was clearly measurable after 5 yr. Assuming the tissue edges advanced continuously during that time, they averaged $2.2 \pm$ $0.69 \mathrm{~cm} \mathrm{yr}^{-1}$, a rate clearly capable of displacing the host tissue (Table 3). No new separate patches of gold coral were seen on the same colonies (Fig. 4). The spread of gold coral tissue was more rapid where the tissue patches had a greater number of branches to travel along $\left(r_{S}=9.48, p<0.05\right)$. This was most obvious for 1 colony (pot 11), where the tissue began at a branch intersection, and in $5 \mathrm{yr}$, the gold coral had radiated along all of the branches simultaneously, nearly covering the entire host and increasing the diameter of the basal holdfast. Some branch loss from the host was observed for 2 of the colonies (pots 11 and 12).

\section{Toppled colonies and remnants of the host}

The gold coral colony marked in the 2000 study (Parrish \& Roark 2009) and then found toppled but alive in 2007 was half dead when it was revisited $5 \mathrm{yr}$ later in 2012. Most of the underside polyps were absent, but since the coral toppled sometime between 5 and 12 yr earlier, it shows that the rates of tissue die-off can be slow. Other examples of persistence after falling included observations of 12 large $(\sim 100 \mathrm{~cm}$ tall) toppled gold coral colonies with 10 to $100 \%$ live tissue. Three of these colonies exhibited growth (5 to 11 sprigs) directed upward from the seafloor (Fig. 5Ai). The sprigs seen on any single colony were roughly of the same height and among the 3 colonies ranged from 40 to $70 \mathrm{~cm}$. Despite the extensive time required to grow the new protein skeleton for these vertical sprigs (Roark et al. 2006), the dead and bare portion of the fallen skeletons still remained smooth and shiny, indicating that skeletal decay is very slow.

The 9 toppled gold coral colonies collected for sectioning were of planar morphology and comprised the tall end of the size structure seen in the community surveys (mean $100.3 \pm 34.2 \mathrm{~cm}$ ) (Table 4). The bare skeleton of 2 colonies with some live tissue remaining were smooth and shiny, whereas the 7 fully dead colonies ranged from a dull shine to delaminated protein rings with lots of external scaling on the surface. Bio-fouling was limited to colonization by other zoanthids, with occasional settlement of corals (e.g. Isididae, Coralliidae). Most of the fouling organisms were small, but there were rare cases of large corals growing on the dead gold coral skeletons (Fig. 5Aii). The cross sections of the skeletons showed the protein laminates of the gold coral layered concentrically (Fig. 5Bi) around the remains of the white carbonate host, which was discernable at the core of the stem for 8 colonies. The core ranged from 2 to $20 \mathrm{~mm}$ in diameter (2 to $42 \%$ of the overall gold colony diameter) and ended abruptly in all specimens. It extended an average of $9.8 \mathrm{~cm}$ in height from the base before the gold coral branches continued independently (Fig. 5Bii). There was no correlation between the height of the host core and its diameter at the base $\left(r_{S}=0.40, n=9, p=0.14\right)$. The basal

Table 3. Four marked (in 2007) and re-measured (in 2012) midas colonies at the Keahole site (see also Fig. 4) by host coral type, height, number of edges and spread of gold coral tissue patch in $5 \mathrm{yr}$, loss of branches, status of the base, and percent of colony left to subsume

\begin{tabular}{|lcccccccc}
\hline Host (pot no.) & $\begin{array}{c}\text { Height } \\
(\mathrm{cm})\end{array}$ & No. of edges & $\begin{array}{c}\text { Gold coral spread } \\
\text { No. of edges } \\
\text { with growth }\end{array}$ & $\begin{array}{c}\text { Spread of } \\
\text { edges }(\mathrm{cm})\end{array}$ & $\begin{array}{c}\text { Total } \\
\text { change }(\mathrm{cm})\end{array}$ & $\begin{array}{c}\text { Branch } \\
\text { loss }(\mathrm{cm})\end{array}$ & $\begin{array}{c}\text { Base } \\
\text { covered }\end{array}$ & $\begin{array}{c}\text { Remaining } \\
\text { host }(\%)\end{array}$ \\
\hline Bamboo (10) & 68.5 & 2 & 2 & 8 & 16 & 0 & No \\
Bamboo (11) & 45.7 & 7 & 7 & 14.5 & 101 & 15 & Yes & 10 \\
Bamboo (12) & 122 & 8 & 4 & 8.1 & 24.5 & 128 & No & 55 \\
Soft coral (41) & 20.5 & 2 & 1 & 13.5 & 13.5 & 0 & No \\
\hline
\end{tabular}



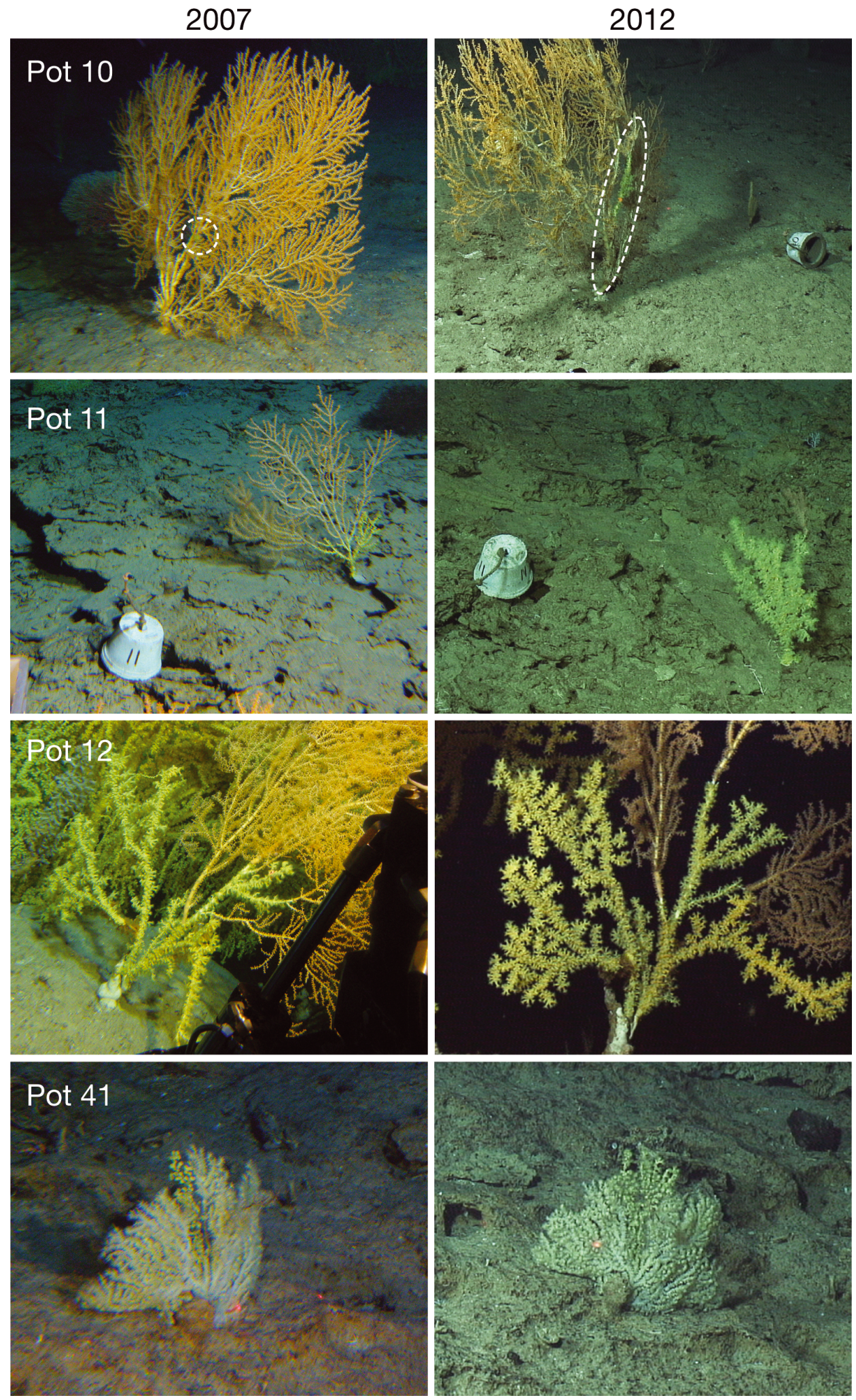

Fig. 4. Before and after photos of 4 midas colonies marked in 2007 (left side) and revisited in 2012 (right side). The top 3 rows (pots 10 to 12) are bamboo coral hosts, and the bottom row (pot 41) is a Calligorgia host. Circles in the first row (depicted by white dashed lines) indicate the initial settlement of gold coral tissue seen in 2007 as a few polyps and the subsequent expan- 

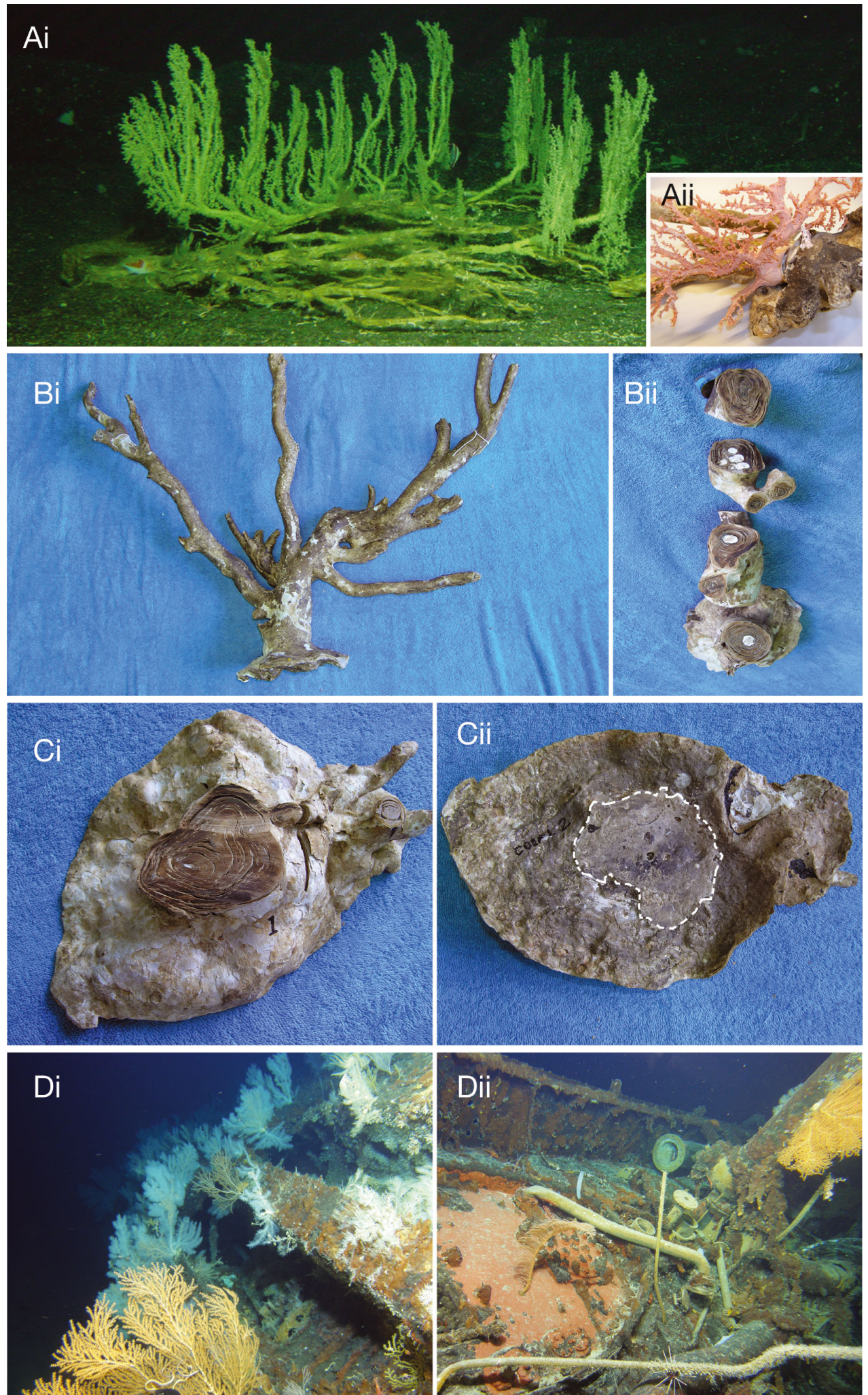

Fig. 5. (Ai) Toppled gold coral with sprigs of new vertical growth and (Aii) dead gold coral skeleton colonized by a full-size Corallium lauuense. (Bi) Dead skeleton, with (Bii) sections of base and stem showing carbonate host extending only partially up the core. (Ci) Cross section of the top side of another colony's base and (Cii) carbonate holdfast within the gold coral base, indicated by white dashed lines. (Di,ii) Bamboo coral colonies growing on the bow and amidships, respectively, of the 'S-19' World War I submarine wreck 
Table 4. Nine toppled gold coral skeletons that were sectioned to determine the extent of the carbonate host colony that remained. Colony sample, date, depth, and status are listed, with height and holdfast diameter of the host and the gold coral parasite and the height and stem diameter of the host that comprised the core of the skeleton. FFS: French Frigate Shoals

\begin{tabular}{|c|c|c|c|c|c|c|c|c|}
\hline \multirow[t]{2}{*}{ Sample } & \multirow{2}{*}{$\begin{array}{c}\text { Date } \\
(\mathrm{mm} / \mathrm{dd} / \mathrm{yy})\end{array}$} & \multirow{2}{*}{$\begin{array}{l}\text { Depth } \\
\text { (m) }\end{array}$} & \multirow[t]{2}{*}{ Status } & \multirow{2}{*}{$\begin{array}{l}\text { Height } \\
\text { (cm) }\end{array}$} & \multicolumn{2}{|c|}{ — Holdfast $(\mathrm{cm})-$} & \multicolumn{2}{|c|}{ — Host stem $(\mathrm{cm})-$} \\
\hline & & & & & Host & Gold coral & Diameter & Height \\
\hline Cross 1 & $11 / 29 / 07$ & 385 & Dead & 96 & 11.7 & 41 & 2 & 2 \\
\hline Cross 2 & $11 / 29 / 07$ & 385 & Dead & 130 & 12.6 & 33 & 0.2 & 2.5 \\
\hline Cross 3 & $11 / 29 / 07$ & 385 & Dead & 102 & 0.5 & 14 & 0.2 & 2 \\
\hline Keahole 4 & $11 / 30 / 07$ & 388 & Dead & 102 & 7 & 19 & 1.7 & 24 \\
\hline Cross 5 & $11 / 29 / 07$ & 385 & Dead & 146 & 9.5 & 28 & 0 & 0 \\
\hline Keahole 6 & $11 / 19 / 00$ & 388 & Dead & 65 & 4 & 30 & 0.7 & 30 \\
\hline FFS & $9 / 16 / 98$ & 352 & Dead & 32 & 1.5 & 7 & 1.5 & 4 \\
\hline Keahole A & $6 / 21 / 12$ & 403 & Live & 120 & 0 & 20 & 0.5 & 10 \\
\hline Keahole B & $6 / 21 / 12$ & 395 & Live & 110 & 0 & 15 & 0.3 & 11 \\
\hline
\end{tabular}

holdfasts were still attached to all of the colonies (Fig. 5Ci), suggesting that the colonies fell when they were large enough for the drag force of the passing water column to exceed the holding power of the holdfast. The holdfasts of the carbonate host averaged a fifth the size of the larger overgrowing gold coral holdfast (Fig. 5Cii).

\section{Recruitment to new habitat}

The survey of the scuttled World War I submarine 'S-19' found 11 colonies of bamboo coral whose heights ranged from 15 to $50 \mathrm{~cm}$ (mean $25 \mathrm{~cm}$, SD 12.4). The largest bamboo colony was estimated to be $55 \mathrm{yr}$ in age. No midas or gold coral colonies were observed. The bamboo coral had settled on the bow, amidships (Fig. 5Di,ii), and stern. A survey of the natural community on the nearest rock pinnacle found a stand of 23 mature gold corals averaging $78 \mathrm{~cm}$ (SD 23.5) in height, with only 2 bamboo corals that were 25 and $60 \mathrm{~cm}$ in height. The morphology and color of the bamboo colonies at the pinnacle were similar to those seen growing on the 'S-19,' suggesting that they were the same species. The rock pinnacle had 1 midas colony present, and its host was a $15 \mathrm{~cm}$ tall antipatharian. During the 2 dives made at the site, the prevailing current was observed travelling from the pinnacle toward the 'S-19.'

\section{DISCUSSION}

\section{Community patterns and the process of succession}

The dispersal of gold coral depends on the pioneering success of other deep corals that disperse to new places, settle, and grow. Once the gold coral arrives, it colonizes a host, propagates, and transforms the community to a new equilibrium. Often referred to as a climax community, this state of development is an endpoint of succession because maturing hosts are relegated to become gold coral habitat (Clements 1936, McCook 1994). Grigg \& Maragos (1974) showed this process in shallow coral communities by comparing the state of succession of recent and known-age lava fields on the Big Island of Hawaii. For deep-sea corals, the present work suggests that there is a facilitative mechanism of succession, with the climax stage occurring when dominance of the community shifts (Freiwald et al. 2004) from a relatively shortlived species (bamboo and other soft corals) to the long-lived gold coral species. The greater the elapsed time, the more the community shifts to a sustained state of gold coral dominance. The patterns seen across the island chain cannot be attributed to latitudinal differences in the environment. Cross Seamount, the oldest site, with a mature gold coral population, is also the southernmost, sharing the same environment as sites with fewer corals (Westpac, Makapuu, Keahole). The role of environmental variables including current flow, particulate fluxes, and productivity (Huff et al. 2013) in this depth range is not known. However, data loggers have monitored temperature in coral beds $(5+\mathrm{yr})$ across the archipelago and found it stable, varying between 8 and $11^{\circ} \mathrm{C}$ (Table 1) (Parrish \& Roark 2009). Whatever the regional environmental effects are, their influence on the process of succession is probably minor when compared to the effect of time. At all but the youngest site (Keahole), enough time had passed for gold coral succession to progress to the climax stage, where the size structure of the bamboo host population was truncated. The significantly larger bamboo 
colonies seen at Keahole were growing on a young ( 250 000 yr) carbonate fossil reef (Jones 1995) drowned by sea level rise and subsidence of the Big Island (Shackleton 1987, Fletcher et al. 2008). During this brief geologic instant, the community at the Keahole site had developed to include mature, toppled, and weathered gold coral colonies, indicating that gold coral had been present at the site for many millennia and was still in the process of transforming the host population. Fundamental to the succession process is the ability of gold coral to gain on its host population, and this is accomplished by its planula settling and rapidly subsuming the host - the midas phase.

\section{Colonization: the midas phase}

The rapid spread of gold coral tissue across the hosts of the 4 marked midas colonies is apparent but not understood. With just 1 repeat observation, we assume that the expansion of the tissue was continuous, but it may have occurred in pulses. There was no gap between the edges of the gold coral tissue and the host tissues to indicate host retraction (Sammarco et al. 1983). There was no band of necrotic tissue, where the eroding edge of the host was being removed by the advancing gold coral tissue. It is not clear if the seamless border between the 2 tissues is because the gold coral tissue was covering and starving the host tissue below or if some other process was occurring. These are good focus areas for future work. For now, with the current data we can use the observations of the midas colonies and other samples to identify patterns in the host morphology, size, and condition to infer aspects of the life history of gold coral.

The available surface area of a host is probably an important variable in the success of gold coral colonization. The bamboo coral group was clearly the preferred host. However, this group only included branched bamboo corals because there were no observations of gold coral settling on the genetically similar bamboo whip corals (e.g. Lepidisis sp.) (France 2007, Dueñas et al. 2014). The reduced surface area afforded by the single filament of whip coral minimizes settlement opportunity for a drifting gold coral planula. In rare cases, gold coral may settle on and colonize whip corals, but it was not seen. The amount of surface area could also explain the differences in the observed number of midas colonies among the surveyed sites. Keahole, with the greatest number of midas colonies, also has the largest bamboo colonies, which affords more surface area and might generate eddy effects that could further enhance settlement (Sebens et al. 1997). The climax communities at the older sites, where mean host height is reduced, provide less than half the surface area for a gold coral planula to colonize and thus have fewer midas colonies. It is not known if colony height influences settlement in other ways such as changing the proportion of a colony's morphology. Nearly all of the midas colonies had their patch of gold tissue located on the central or lower portion of the host, and this may relate to where a planula can best settle on the living tissue of the host. The cortical tissue of coral colonies is thickest at the distal tips of branches (Watling 2011, Dueñas et al. 2014), and that may be enough to shed a passing planula more than the lower stem and base, where the tissue is thinner and attachment could be easier.

In both the marked midas colonies and the sectioned skeletons, the upper portions of the host skeleton were lost in the process of being subsumed. The reason for this is not known, but it could be the result of increasing water drag associated with the gold tissue replacing the host tissue. Larger polyps of gold coral tissue (Sinniger et al. 2013) means greater drag stressing and weakening the protein nodes of the bamboo skeleton (Tracey et al. 2007) into a series of potential break points. Colonizing a large host colony only to have much of it break away seems selfdefeating, but as long as the gold coral tissue spreads to the base and secures its place on the substrate, it will have achieved settlement at a site that the preceding host has shown to have excellent conditions for suspension feeding. Gold coral's reliance on the small basal portion of the host (mean $12 \%$ ) explains why gold coral and bamboo coral colonies rarely have the same shape. If more of the host skeleton were retained, then we would expect the gold coral branch pattern to be more bilateral like its host instead of the asymmetry that is commonly seen. Also, because the host is cropped down to its stem, and the host height contributes little to the gold coral colony, the linear radiometric growth estimates for mature gold coral colonies are valid (Roark et al. 2006).

\section{Slow death and decay}

When a gold coral colony topples, its future depends on its exposure to water flow in its new orientation. Without flow, it will slowly die. With some flow, it will likely undergo a mix of tissue loss and continued growth that adapts to its new orientation. 
The extent of any new vertical growth on a fallen colony should be proportional to the number of years since the colony fell. For example, using the radiometric growth rate, the colony observed with new sprigs that average $70 \mathrm{~cm}$ in height would have fallen $\sim 300$ yr ago (Roark et al. 2006). The live portion of the toppled colony will continue to grow and produce planulae, contributing to the process of community succession, for many years to come. It will only persist as long as the dead portion of this colony anchors it, and given the low level of bio-erosion at subphotic depths, this can be a very long time. In 3 centuries, the dead portion of the colony had dulled in color but was still smooth. Most coral families that colonized the dead gold coral stumps, such as Coralliidae or Isididae, will have shorter lifespans (Roark et al. 2005, 2006, Tracey et al. 2007, Andrews et al. 2009) and thus will be easily accommodated by gold coral's slow rate of decay. No other deep-sea coral species in Hawaii has been identified to be as long-lived, abundant, and able to persist after toppling as gold coral.

\section{Dispersal and recruitment}

Even though gold coral was found at all of the islands and banks surveyed, the pioneering planulae responsible for this dispersal were probably the exceptions to what was mostly localized recruitment. Gold coral and its bamboo coral host are broadcast spawners (Mercier \& Hamel 2011, Beazley \& Kenchington 2012), with synchronized spawning thought to occur during warmer times of the year (Parker et al. 1997, Waller \& Baco 2007, Bo 2008). The volume of gametes released is a function of the size of the parent colony (Grigg 1988), producing greater fecundity through more polyps (Waller \& Baco 2007). A review of the connectivity for known deep-sea benthic species in relation to biological and oceanographic processes estimated the minimum planktonic larval duration for settlement to be $35 \mathrm{~d}$ for half of the species and $69 \mathrm{~d}$ to achieve three-quarters (Hilario et al. 2015). Even though the dispersal range of benthic invertebrates (Todd 1998), including deep-sea corals, can extend across oceanic expanses (Smith et al. 2004), the bulk of settlement occurs locally (Grigg 1965, 1988, Kinlan \& Gaines 2003). Shallow-water studies comparing broadcast taxa with brooding corals indicate that localized recruitment occurs regardless of life history type (Richmond 1988), and recruitment is heavily influenced by timing, environmental conditions, and synchronous vs. asynchronous release (Richmond \& Hunter 1990).
The corals growing on the 'S-19' illustrate the spatial barriers and time lags associated with gold coral reaching a new place and starting succession in a community. Proximity to a larval source is an important variable influencing the speed at which a gold coral planula finds a host. Even though a mature patch of gold corals grew a short distance up-current, they were absent at the coral community of the 'S-19.' Distance quickly dilutes the release of planulae from parent colonies to a sparse level that diminishes the farther they drift (Sammarco \& Andrews 1988). Also, a gold coral planula has fewer options for settlement than its host. The bamboo coral (which comprised only $8 \%$ of corals at the pinnacle community) has a greater probability of encountering settlement options on the $66 \mathrm{~m}$ long 'S-19' hull than a gold coral planula whose settlement is limited to a small number of hosts growing on the hull. It is unknown how long it will be before a gold coral pioneer settles and begins to transform the 'S-19' site. Once the first gold coral settles and matures (assuming recruitment is indeed localized), the rate of subsequent colonization at the 'S-19' should increase considerably. Finally, the time lag between the host and parasite is essential to the life history of gold coral; if gold coral planulae were numerous in space and time, they would quickly saturate all of the available hosts with settlers and subsume them at a rate faster than the host population could replenish.

\section{CONCLUSIONS}

Gold coral planulae tend to settle on taller bamboo corals. Over time, this changes the deep coral community to a new point of equilibrium, where the number of gold coral colonies equals or exceeds that of the bamboo corals, effectively truncating the size structure of the host population. The midas phase, when a gold coral planula attaches, spreads, and subsumes the host, is the most rapid growth period of the gold coral life history. During this phase, significant branch loss of the host skeleton indicates that gold coral exploits the viability of the host's location for growth and survival and depends little on the potential advancement from the height of the host. Gold coral settlement was greatest on hosts found close to mature gold coral colonies. This indicates that with greater distance, greater time is required for a gold coral planula to arrive and initiate the next stage of succession. 
Acknowledgements. Submersible time on the 'Pisces IV' and 'Pisces V' was provided by the Hawaii Fisheries Disaster Relief Program, NOAA Fisheries Office of Science and Technology, and the Hawaii Undersea Research Laboratory (HURL). Dives in the northwestern Hawaiian Islands were conducted under a permit from the Papahanamokuakea National Marine Monument. Decades of work using the 'Pisces' submersibles have shown them to be an invaluable scientific asset matched only by the professionalism of the HURL team that operates them. Thanks to the pilots, sub techs, and support staff who enthusiastically worked to achieve success on every dive. Graphic support was provided by Bryan Dieter and Deborah Yamaguchi; and the manuscript was improved with helpful comments from Edward DeMartini, Allen Andrews, and 3 anonymous reviewers. Publication costs were covered by the NOAA Deep Sea Coral Research and Technology Program.

\section{LITERATURE CITED}

Andrews AH, Stone RP, Lundstrom CC, DeVogelaere AP (2009) Growth rate and age determination of bamboo corals from the northeastern Pacific Ocean using refined ${ }^{210} \mathrm{~Pb}$ dating. Mar Ecol Prog Ser 397:173-185

Beazley LI, Kenchington EL (2012) Reproductive biology of the deep-water coral Acanella arbuscula (Phylum Cnidaria: Class Anthozoa: Order Alcyonacea), northwest Atlantic. Deep-Sea Res I 68:92-104

Bo M (2008) Taxonomy and ecology of antipatharians. PhD dissertation, Universitia Politenica Delle Marche, Ancona

> Clements FE (1936) Nature and structure of the climax. Ecology 24:252-284

Cohen J (1988) Statistical power analysis for the behavioral sciences, 2nd edn. Laurence Erlbaum Associates, Hillsdale, NJ

> Druffel ERM, Griffin S, Witter A, Nelson E, Southon J, Kashgarian M, Vogel J (1995) Gerardia: bristlecone pine of the deep-sea? Geochim Cosmochim Acta 59:5031-5036

Dueñas LF, Alderslade P, Sanchez JA (2014) Molecular systematics of the deep-sea bamboo corals (Octocorallia: Isididae: Keratisidinae) from New Zealand with descriptions of two new species of Keratoisis. Mol Phylogenet Evol 74:15-28

Fletcher $\mathrm{CH}$, Bochicchio $\mathrm{C}$, Conger $\mathrm{CL}$, Engels $\mathrm{MS}$ and others (2008) Geology of Hawaii reefs. In: Riegl B, Dodge RE (eds) Coral reefs of the USA. Springer Science, Dordrecht, p 435-487

France SC (2007) Genetic analysis of bamboo corals (Cnidaria: Octocorallia: Isididae): Does lack of colony branching distinguish Lepidisis from Keratoisis? Bull Mar Sci 81:323-333

Freiwald A, Fossa JH, Grehan A, Koslow T, Roberts JM (2004) Cold-water coral reefs. UNEP-WCMC, Cambridge

Garcia MO, Smith JR, Tree JP, Weis D, Harrison L, Jicha BR (2015) Petrology, geochemistry, and ages of lavas from northwest Hawaiian Ridge volcanoes. In: Neal CR, Sager WW, Sano T, Erba E (eds) The origin, evolution, and environmental impact of oceanic large igneous provinces. Geol Soc Am Spec Paper 511:1-25

- Griffith JK (1994) Predation on soft corals (Octocorallia: Alcyonacea) on the Great Barrier Reef, Australia. Aust J Mar Freshw Res 45:1281-1284

Grigg RW (1965) Ecological studies of black coral in Hawaii. Pac Sci 19:244-260
Grigg RW (1988) Recruitment limitation of a deep benthic hard-bottom octocoral population in the Hawaiian Islands. Mar Ecol Prog Ser 45:121-126

Grigg RW (1993) Precious coral fisheries of Hawaii and the US Pacific Islands. Mar Fish Rev 55:50-60

Grigg RW (2001) Black coral: history of a sustainable fishery in Hawaii. Pac Sci 55:291-299

Grigg RW (2002) Precious corals in Hawaii: discovery of a new bed and revised management measures for existing beds. Mar Fish Rev 64:13-20

Grigg RW, Maragos JE (1974) Recolonization of hermatypic corals on submerged lava flows in Hawaii. Ecology 55: 389-395

Hilario A, Metaxas A, Gaudron SM, Howell KL and others (2015) Estimating dispersal distance in the deep sea: challenges and applications to marine reserves. Front Mar Sci 2:6

- Huff DD, Yoklavich MM, Love MS, Watters DL, Chai F, Lindley ST (2013) Environmental factors that influence the distribution, size, and biotic relationships of the Christmas tree coral Antipathes dendrochristos in the Southern California Bight. Mar Ecol Prog Ser 494:159-177

Jones AT (1995) Geochronology of drowned Hawaiian coral reefs. Sediment Geol 99:233-242

> Kinlan BP, Gaines SD (2003) Propagule dispersal in marine and terrestrial environments: a community perspective. Ecology 84:2007-2020

> Mah C, Nizinski M, Lundsten L (2010) Phylogenetic revision of the Hippasterinae (Goniasteridae: Asteroidea): systematics of deep sea corallivores including one new genus and three new species. Zool J Linn Soc 160: 266-301

> McCook LJ (1994) Understanding ecological community succession: causal models and theories, a review. Vegetatio 110:115-147

- Mercier A, Hamel JF (2011) Contrasting reproductive strategies in three deep-sea octocorals from eastern Canada: Priminoa resedaeformis, Keratoisis ornate, and Anthomastus grandifloras. Coral Reefs 30:337-350

Muzik K (1978) A bioluminescent gorgonian Lepidisis olapa, new species (Coelenterata, Octocorallia) from Hawaii. Bull Mar Sci 28:735-741

> Parker NR, Mladenov PV, Grange KR (1997) Reproductive biology of the antipatharian black coral Antipathes fiordensis in Doubtful Sound, Fiordland, New Zealand. Mar Biol 130:11-22

Parrish FA, Baco AR (2007) State of deep coral ecosystems in the U.S. Pacific Islands region: Hawaii and the U.S. Pacific territories. In: Lumsden SE, Hourigan TF, Bruckner AW, Dorr G (eds) The state of deep coral ecosystems of the United States. NOAA Tech Memo CRCP-3, Silver Spring, MD, p 155-294

Parrish FA, Roark EB (2009) Growth validation of gold coral Gerardia sp. in the Hawaiian Archipelago. Mar Ecol Prog Ser 397:163-172

Richmond RH (1988) Competency and dispersal potential of planula larvae of a spawning versus a brooding coral. Proc 6th Int Coral Reef Symp, Townsville 2:827-831

Richmond RH, Hunter CL (1990) Reproduction and recruitment of corals: comparison among the Caribbean, the Tropical Pacific, and the Red Sea. Mar Ecol Prog Ser 60: 185-203

> Roark EB, Guilderson TP, Flood-Page S, Dunbar RB, Ingram BL, Fallon SJ, McCulloch M (2005) Radiocarbon-based ages and growth rates of bamboo corals from the Gulf of 
Alaska. Geophys Res Let 32:L04606, doi:10.1029/2004GL 021919

Roark EB, Guilderson TP, Dunbar RB, Ingram BL (2006) Radiocarbon-based ages and growth rates of Hawaiian deep-sea corals. Mar Ecol Prog Ser 327:1-14

Roark EB, Guilderson TP, Dunbar RB, Fallon SJ, Shester GS, Mucciarone DA (2009) Extreme longevity in proteinaceous deep-sea corals. Proc Natl Acad Sci USA 106: 5204-5208

Sammarco PW, Andrews JC (1988) Localized dispersal and recruitment in the Great Barrier Reef corals: the Helix experiment. Science 239:1422-1424

Sammarco PW, Coll JC, La Barre S, Willis B (1983) Competitive strategies of soft corals (Coelenterata: Octocorallia): allelopathic effects on selected scleractinian corals. Coral Reefs 1:173-178

Sebens KP, Witting J, Helmuth B (1997) Effects of water flow and branch spacing on particle capture by the reef coral Madracis mirabilis (Duchassaing and Michelotti). J Exp Mar Biol Ecol 211:1-28

Shackleton NJ (1987) Oxygen isotopes, ice volume and sea level. Quat Sci Rev 6:183-190

Siegel S, Castellan NJ Jr (1988) Nonparametric statistics for the behavioral sciences, 2nd edn. McGraw-Hill, New York, NY

Editorial responsibility: Joseph Pawlik, Wilmington, North Carolina, USA
Sinniger F, Ocana OV, Baco AR (2013) Diversity of zoanthids (Anthozoa: Hexacorallia) on Hawaiian seamounts: description of the Hawaiian gold coral and additional zoanthids. PLoS ONE 8:e52607

Smith PJ, McVeagh SM, Mingoia JJ, France SC (2004) Mitochondrial DNA sequence variation in deep-sea bamboo corals (Keratoisidinae) species in the southwest and northwest Pacific Ocean. Mar Biol 144:253-261

Tilling RI, Heliker C, Swanson DA (2010) Eruptions of Hawaiian volcanos - past, present, and future. US Geological Survey General Information Product 117, Reston, VA

Todd CD (1998) Larval supply and recruitment of benthic invertebrates: Do larvae always disperse as much as we believe? Hydrobiologia 375/376:1-21

Tracey DM, Neil H, Marriott P, Andrews AH, Calliet GM, Sanchez JA (2007) Age and growth of two genera of deepsea bamboo corals (family Isididae) in New Zealand waters. Bull Mar Sci 81:393-408

Waller RG, Baco AR (2007) Reproductive morphology of three species of deep-water precious corals from the Hawaiian Archipelago: Gerardia sp., Corallium secundum, and Corallium lauuense. Bull Mar Sci 81:533-542

Watling L, France SC, Pante E, Simpson A (2011) Biology of deep-water octocorals. Adv Mar Biol 60:41-122

Submitted: March 2, 2015; Accepted: June 8, 2015

Proofs received from author(s): July 23, 2015 